\title{
Soil-borne and compost-borne Penicillium sp. and Gliocladium spp. as potential microbial biocontrol agents for the suppression of anthracnose-induced decay on tomato fruits
}

\author{
Marwa Hassine ${ }^{1 *}$, Rania Aydi-Ben-Abdallah², Hayfa Jabnoun-Khireddine ${ }^{2}$ and Mejda Daami-Remadi ${ }^{2}$
}

\begin{abstract}
Background: Anthracnose is a soil-borne tomato (Solanum lycopersicum L.) disease caused by Colletotrichum coccodes and associated with early dying syndrome and postharvest fruits decays leading to significant yield losses. A biocontrol trial was conducted using Penicillium sp. and Gliocladium spp. isolates recovered from soil and compost for the evaluation of their antifungal potential against the target pathogen.

Results: Cell-free culture filtrates of the microbial agents tested at different concentrations displayed an important antifungal activity based on pathogen mycelial growth inhibition and spore germination suppression. The highest antifungal potential was induced by Penicillium sp. CH6, G. catenulatum Gc1 and G. virens Gv1 cell-free filtrates applied at 3 concentrations $(10,15$ and $20 \% \mathrm{v} / \mathrm{v})$. C. coccodes mycelial growth was significantly reduced by 16 to $84 \%$ with chloroform and ethyl acetate extracts of Penicillium sp. CH6 and G. catenulatum Gc1 isolates applied at the concentrations 1, 2.5 and $5 \% \mathrm{v} / \mathrm{v}$. These treatments had induced an important morphological alteration to pathogen mycelium expressed mainly by a decrease in colony melanization. Testing on pathogen-inoculated fruits, treatment based on cell-free culture filtrates and organic extracts had significantly reduced anthracnose severity as compared to control. Rot lesion diameter was significantly decreased about $22 \%$ following treatments with Penicillium sp. CH6 and G. catenulatum Gc1 cell-free filtrates. All chloroform and ethyl acetate extracts of isolates tested had suppressed disease severity by 11 to $59 \%$ and 14 to $85 \%$, respectively, as compared to the untreated control.
\end{abstract}

Conclusions: The results demonstrated the involvement of bioactive compounds in the cultural filtrates and organic extracts tested. These microbial agents may be explored as an alternative tool for the protection of tomato fruits from fungi-associated decays.

Keywords: Antifungal activity, Biological control, Culture filtrates, Gliocladium spp., Organic extracts, Penicillium sp., Tomato rot

\footnotetext{
*Correspondence: marwa.hassine1@gmail.com

1 LR14AGR01, Laboratory of Genetics and Cereal Breeding, National Agronomic Institute of Tunisia, University of Carthage, Avenue Charles Nicolle 43, 1082 Tunis, Tunisia

Full list of author information is available at the end of the article
}

\begin{abstract}
Background
Anthracnose is a soil-borne disease caused by various Colletotrichum species on a wide range of hosts estimated at more than 460 plant species such as pepper, pumpkin, papaya and tomato (Solanum lycopersicum L.) (Ridzuan et al. 2018). C. coccodes is one of the most widespread species in almost all tomato production areas and caused considerable economic losses
\end{abstract}


(Gilardi et al. 2014) reaching up to 50\% in some African countries (Ibrahim et al. 2011). As a hemibiotrophic pathogen, it is responsible of root rots and fruit decays in the field during rainy weather (Sanoubar and Barbanti 2017) and during the period of pre- or postharvest ripening and storage (Sonawane and Shinde 2021). The colonization of unripe, living-host fruit tissue and fruit ripening occurs during the active necrotrophic stage (Alkan et al. 2009). This stage has led to the splashing of the spores of C. coccodes on the ripe or overripe fruit. Green fruit could be also infected and symptoms started to develop during tomatoes maturity (Sanoubar and Barbanti 2017). The typical lesions occurring on ripe fruits are black circular with concentric ring, black spores and depressed leading to reduced marketable fruit quality (Opeyemi et al. 2018). The development of these symptoms depends on the cultivation practices during harvest, transport, storage and marketing (Badawy and Rabea 2009) combined with the high levels of humidity and low temperatures. For disease control, chemical treatments in combination with radiation treatments, hot water soaking and refrigeration (Shu et al. 2017) were mainly applied at the postharvest phase due to their important satisfactory effect and their effective control on the prevention of the infection and the dispersal of the fungus (Huang et al. 2020). Unfortunately, the excessive and long-term use of several postharvest chemical fungicides has led to the development of resistant strains (Jaihan et al. 2018). Furthermore, this synthetic chemical fungicide applied to maintain fruit quality has easily created a serious environmental pollution and human health risk because of the difficult degradation and nontarget toxicity (Miftahurrohmat et al. 2021). These environmental concerns and the consumer awareness of the relationship between foods and health have actually contributed to the promotion of the organic tomato culture (Riahi et al. 2009). In this context, several alternative protection strategies including soil solarization, grafting, biofumigation, biological soil disinfestations, application of biocontrol agents and organic amendments were explored (Opeyemi et al. 2018). The biological control approach is a promising approach against plant diseases and more focused on the use of the different microorganisms isolated from various sources (Gu et al. 2020). Gliocladium virens, G. catenulatum (CwalinaAmbroziak and Nowak 2012) and Penicillium sp. (Rahman et al. 2018) were widely explored by researchers due to their efficiency against various plant diseases (Atalla et al. 2020). Production of cell wall-degrading enzymes, mycoparasitism, competition for nutrients or space antibiotic production and the induction of defense responses were the main reported mechanisms of action (Jinal and Amaresan 2020).

The aim of the present investigation was to evaluate the in vitro antifungal potential of the cell-free cultural filtrates and the organic extracts of various microbial agents belonging to Penicillium sp. and Gliocladium spp. against $C$. coccodes and their ability to suppress anthracnose development and severity on tomato fruits.

\section{Methods \\ Fungal material \\ Pathogen isolation and culture}

The soil-borne fungal pathogen (C. coccodes) used in the present study was isolated from tomato cv. Rio Grande fruits, showing typical anthracnose symptoms. Pathogen identification was carried out in the laboratory of Phytopathology of the Regional Research Centre on Horticulture and Organic Agriculture of Chott-Mariem (CRRHAB), Tunisia, based on cultural and morphological traits. This pathogen was grown on potato dextrose agar (PDA) medium (Accumix ${ }^{\mathrm{TM}}$ ) amended with streptomycin sulfate $(300 \mathrm{mg} / \mathrm{l})(\mathrm{w} / \mathrm{v})$ and incubated during 15 days at $25^{\circ} \mathrm{C}$ in the dark before use (Maatougui and Merzoug 1997).

\section{Microbial biocontrol agents: isolation source and growth conditions}

Eight isolates of Penicillium sp., one isolate of Gliocladium virens and one isolate of G. catenulatum were isolated from compost and tomato roots as detailed (Table 1). They were identified based on their morphological and cultural traits (Kubicek and Harman 1998) and stored in the culture collection of the laboratory of phytopathology of the Regional Research Centre on Horticulture and Organic Agriculture of Chott-Mariem (CRRHAB), Tunisia. Their antagonistic potential has been previously proven on many phytopathogens

Table 1 Origin of the different microbial agents used for tomato anthracnose biocontrol

\begin{tabular}{lll}
\hline Isolate & Code & Isolation source \\
\hline Penicillium sp. & $\mathrm{CH} 5$ & Compost \\
& $\mathrm{CH} 6$ & Compost \\
& $\mathrm{CH} 7$ & Compost \\
& $\mathrm{CH} 9$ & Compost \\
& $\mathrm{CH} 11$ & Compost \\
& $\mathrm{MC} 1$ & Compost \\
& $\mathrm{MC} 3$ & Compost \\
& $\mathrm{MC} 4$ & Compost \\
Gliocladium virens & $\mathrm{Gv} 1$ & Tomato roots \\
Gliocladium catenulatum & $\mathrm{GC1}$ & Tomato roots \\
\hline
\end{tabular}


(Daami-Remadi et al. 2012). They were cultivated on PDA medium and incubated at $25{ }^{\circ} \mathrm{C}$ in the dark during 7 days, as described by Comporta (1985), before being used for further assays and in vivo inoculation.

\section{Plant material}

The experiment was conducted in vivo using the widely cultivated Tunisian tomato cultivar Rio Grande. Tomato fruits were selected according to their maturity, firmness, consistency and the absence of any apparent rot symptoms on their surfaces. They were surface-disinfected with $10 \%$ sodium hypochlorite for $5 \mathrm{~min}$, then rinsed with sterile distilled water (SDW) and air-dried before use.

\section{Assessment of the antifungal potential of the microbial agents tested}

In vitro potential of cell-free culture filtrates

The different microbial agents were transferred from Petri plates to 200-ml Erlenmeyer flasks containing $100 \mathrm{ml}$ of potato dextrose broth (PDB) medium (Accu$\left.\mathrm{mix}^{\mathrm{TM}}\right)$. These liquid cultures were then incubated at room temperature on a rotary shaker at $150 \mathrm{rpm} / \mathrm{min}$ during15 days (Dennis and Webster 1971). They were centrifuged thrice at 10,000 rpm for $10 \mathrm{~min}$. Supernatant fluids were sterilized by filtration through $0.22-\mu \mathrm{m}$ millipore size filter (Lepengue et al. 2009). The extracted filtrates were aseptically added to molten PDA medium cooled at $45^{\circ} \mathrm{C}$ and supplemented with Streptomycin sulfate $(300 \mathrm{mg} / \mathrm{l})$ at the concentrations $(10 \%, \mathrm{v} / \mathrm{v})$ and poured into Petri plates. After solidification of the mixture, three 6-mmdiameter mycelial-agar plugs, removed from C. coccodes cultures, were placed equidistantly in each Petri plate. Fungal cultures were incubated at $25{ }^{\circ} \mathrm{C}$ for 7 days. The effect of the tested culture filtrates on pathogen growth was estimated based on colony diameter compared to the untreated control. The mycelial growth inhibition rate (\%) was calculated using the following formula:

$$
I \%=\left[\frac{(C 1-C 2)}{C 1}\right] * 100
$$

where C1: mean colony diameter in control plates and $C 2$ : mean colony diameter in filtrate-amended plates.

The most active cell-free cultural filtrates of the tested biocontrol strains in reducing $C$. coccodes spore germination and mycelial growth were further screened at three concentrations $(10,15$ and $20 \%, \mathrm{v} / \mathrm{v})$ and amended to PDA medium as described above. The solidified agar plates were inoculated by triplicate mycelial agar plugs ( $5 \mathrm{~mm}$ in diameter) and incubated at $25{ }^{\circ} \mathrm{C}$ for 7 days. Plates without microbial filtrates served as control. The pathogen colony diameter was measured and the percentage of radial growth inhibition was calculated as described above.

\section{In vitro potential of organic extracts}

The liquid-liquid extraction of the antifungal metabolites from the microbial cell-free cultural filtrates was carried out only for those showing an interesting antifungal potential against the target pathogen. Two organic solvents were used, i.e., chloroform and ethyl acetate. Ten milliliters from each filtrate, which prepared as described above, were placed in a separating funnel before adding carefully $10 \mathrm{ml}$ of the extraction solvent (Fu et al. 2011). This mixture was reversed several times with degassing from time to time and left to settle (open cap) in order to reach the equilibrium between the two phases. The organic phases of chloroform (the lower phase for extraction) and ethyl acetate (the upper one) were collected and the aqueous phase was replaced in the funnel. This process was repeated 2 other times by adding $10 \mathrm{ml}$ of solvent for each step. The solvent was evaporated using a rotary evaporator at $90{ }^{\circ} \mathrm{C}$ with a slight rotation at $150 \mathrm{rpm}$ (Zain et al. 2011). Each obtained organic phase extract was dissolved into $2 \mathrm{ml}$ of methanol for further antifungal potential analyses against $C$. coccodes (You et al. 2009). This different extract was tested at three concentrations $(1,2.5$, and $5 \%(\mathrm{v} / \mathrm{v}))$ on PDA supplemented with streptomycin sulfate $(300 \mathrm{mg} / \mathrm{ml})$ (Smaoui, 2010). After solidification of the mixture, 3 agar plugs of the pathogen $(6 \mathrm{~mm}$ in diameter) were equidistantly placed in the Petri plate. Fungal colony diameter was measured after 7 days of incubation at $25^{\circ} \mathrm{C}$.

\section{Disease suppressive potential of culture filtrates and organic extracts}

Cell-free cultural filtrates and organic extracts of the microbial agents tested, which prepared as described above, were applied to disinfected tomato fruits by injecting $100 \mu \mathrm{l}$ in each wound (diameter $6 \mathrm{~mm}$ ). Two hours post-treatment, an agar plug colonized by $C$. coccodes was placed within each wound. The positive control was inoculated with the pathogen and treated with a same volume of sterile distilled water only and the negative control was inoculated with un-colonized agar plug and treated similarly using sterile distilled water. All tomato fruits were incubated at $25^{\circ} \mathrm{C}$ for 5 days in plastic boxes to maintain a high relative humidity (Mónaco et al. 2009). The diameter of the lesion developing around inoculated wounds was measured.

\section{Statistical analysis}

All measured parameters were analyzed using the software SPSS 16.0 (Statistical Package for the Social Sciences) using the general linear models (GLM). The 
in vitro effect of culture filtrates and organic extract of the microbial agents tested was analyzed according to a completely randomized design with two factors (culture filtrates or organic extracts tested and concentrations used). Three replications were used for each individual treatment and the whole experiment was repeated twice. For all in vivo trials, each individual treatment was replicated 5 times (five fruits) and the whole experiment was repeated twice. The analyses were conducted according to a completely randomized design when the culture filtrates or the organic extracts tested were the only fixed factor. All data were analyzed using a standard analysis of variance (ANOVA) with interactions. Means comparisons were separated using Student-Newman-Keuls (SNK) and/or LSD test (at $P \leq 0.05$ ).

\section{Results}

\section{Characteristics of colletotrichum coccodes isolate}

After 7 days of incubation on PDA at $25{ }^{\circ} \mathrm{C}, \mathrm{C}$. coccodes isolate obtained from tomato fruit with typical anthracnose symptoms produced sparse white to grey aerial mycelium with abundant black, spherical microsclerotia (av. $2594 \mu \mathrm{m}$ ) that are distributed evenly over the agar surface and ordered in concentric rings. Conidia were hyaline, aseptate and cylindrical $16-26 \times 3-5 \mu \mathrm{m}$, with tapered ends (Fig. 1).

\section{Antifungal potential of the microbial agents tested}

ANOVA analysis revealed significant variation (at $P \leq 0.05)$ in the colony diameter depending on the biocontrol isolates tested and the concentration applied and this for the cell-free cultural filtrates and organic extracts trials. Also, a significant variation in the fruit lesion dimension effect was detected depending on treatments tested (filtrates or organic extracts).

\section{Antifungal potential of cell-free culture filtrates of the tested microbial agents}

Data given in Figs. 2, 3 showed that cultural filtrates from Penicillium sp. (MC4 and $\mathrm{CH} 6$ isolates), and G.

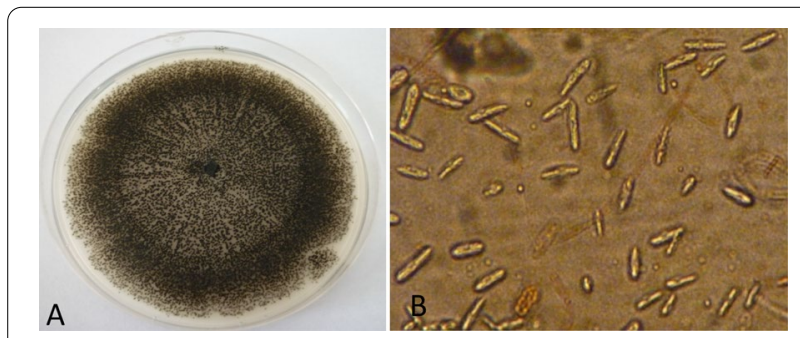

Fig. 1 Colony appearance of Colletotrichum coccodes isolate grown on potato dextrose agar at $25^{\circ} \mathrm{C}$ for 10 days (a) and its cylindrical conidia with round ends $(\times 400)(\mathbf{b})$

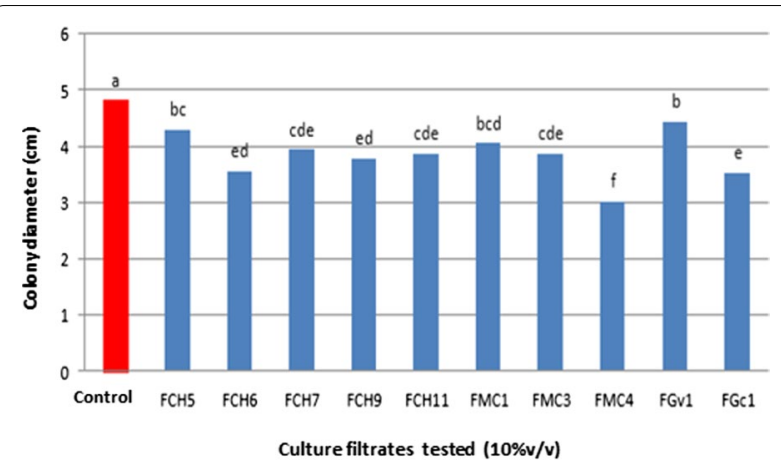

Fig. 2 Antifungal potential of cell-free cultural filtrates of Penicillium sp. and Gliocladium spp. tested at 10\% v/v against Colletotrichum coccodes mycelial growth recorded after 9 days of incubation at $25^{\circ} \mathrm{C}$, compared to the untreated control. FCH5, FCH6, FCH7, FCH9, FCH1 1, FMC1, FMC3 and FMC4: Culture filtrates from Penicillium sp. cultures of $\mathrm{CH} 5, \mathrm{CH} 6, \mathrm{CH} 7, \mathrm{CH} 9, \mathrm{CH} 11, \mathrm{MC1}, \mathrm{MC} 3$ and $\mathrm{MC} 4$ isolates; FGv1: Cultural filtrate of Gliocladium virens (Gv1 isolate); FGc1: Cultural filtrate of $G$. catenulatum (Gc1 isolate). Bars sharing the same letters are not significantly different according to the Student-NewmanKeuls tests at $P \leq 0.05$

catenulatum (Gc1) applied at $10 \%$ had reduced C. coccodes mycelial growth by 37,27 and $26 \%$, respectively, as compared to the untreated control. The remaining isolates exhibited different inhibition rates ranging from 8 to $21 \%$ compared to control. Significant reductions in pathogen spore germination and mycelial melanization were mainly noted following treatments with cell-free culture filtrates from Penicillium sp. (CH5 and CH6), G. catenulatum (Gc1) and G. virens (Gv1) isolates.

\section{Comparative efficiency of cultural filtrates tested depending on concentrations used}

Cultural filtrates of four microbial agents (Penicillium sp. $\mathrm{CH} 5$ and $\mathrm{CH} 6$, G. catenulatum (Gc1) and G. virens (Gv1)) showed a significant inhibitory effect and fixed

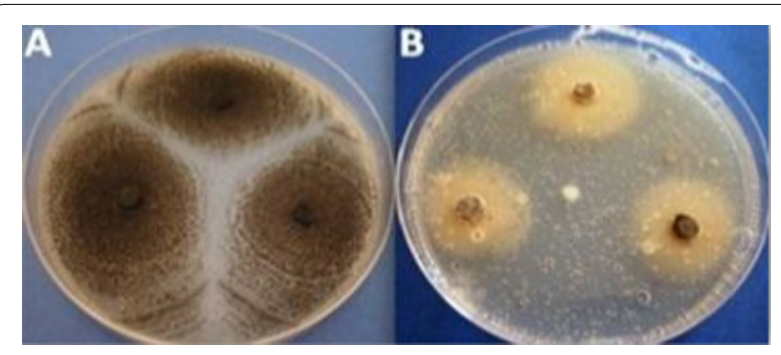

Fig. 3 Reduced growth and altered mycelial density and melanization observed after 9 days of incubation at $25^{\circ} \mathrm{C}$ on Colletotrichum coccodes colonies (b) grown on PDA medium supplemented with Penicillium sp. cell-free filtrate $(\mathrm{CH} 6)$ as compared to the untreated controls (a) 
at $25 \%$ over control, were tested at different concentrations $(10,15$ and $20 \% \mathrm{v} / \mathrm{v})$. ANOVA analysis showed that the diameter of $C$. coccodes colonies significantly varied (at $P \leq 0.05$ ) depending on filtrates tested and concentrations used (Fig. 4). In fact, pathogen mycelial growth was inhibited by 7, 8 and 15\%, compared to the untreated control, when grown on PDA medium amended with $10 \% \mathrm{v} / \mathrm{v}$ of the cultural filtrates of G. catenulatum Gc1, and Penicillium sp. $\mathrm{CH} 5$ and $\mathrm{CH} 6$ isolates, respectively. When applied at $15 \% \mathrm{v} / \mathrm{v}$, treatments with Penicillium sp. CH6, G. catenulatum Gc1 and G. virens Gv1 cultural filtrates had suppressed the in vitro pathogen growth by 19 to $36 \%$ over control, respectively. The highest inhibition rates, ranging from 31 to $60 \%$, were recorded using filtrates at $20 \% \mathrm{v} / \mathrm{v}$. The increase of concentration of filtrates for the CH5 of Penicillium sp. (Fig. 5) and Gv1 of G. virens was associated to an important reduction in spore germination and mycelium melanization of C. coccodes by 80 to $95 \%$ as compared to control.

\section{Antifungal potential of ethyl acetate extracts of microbial agents tested}

The diameters of $C$. coccodes colonies formed after 9 days incubation at $25^{\circ} \mathrm{C}$, varied significantly depending on the tested extracts, the concentrations used, and their interactions (Fig. 6). Treating at 1\% v/v, ethyl acetate extracts of all microbial agents, except that from Penicillium sp. $\mathrm{CH} 6$, had inhibited pathogen growth by 4 to $12 \%$ than the untreated control. However, at the $2.5 \% \mathrm{v} / \mathrm{v}$, only $G$. virens $\mathrm{Gv1}$ and $G$. catenulatum Gc1 extracts had significantly suppressed pathogen growth by 16 and $44 \%$ over control, respectively. More interestingly, the effectiveness of extracts tested applied at $5 \% \mathrm{v} / \mathrm{v}$ had raised to $39-70 \%$ for all tested microbial agents with an important alteration of morphological traits on $C$. coccodes colonies (Figs. 7, 8). Significant reductions in mycelial melanization and spore germination were also noted using extracts at 2.5 to $5 \% \mathrm{v} / \mathrm{v}$ leading to $85 \%$ and $95 \%$ decrease as compared to control, respectively.

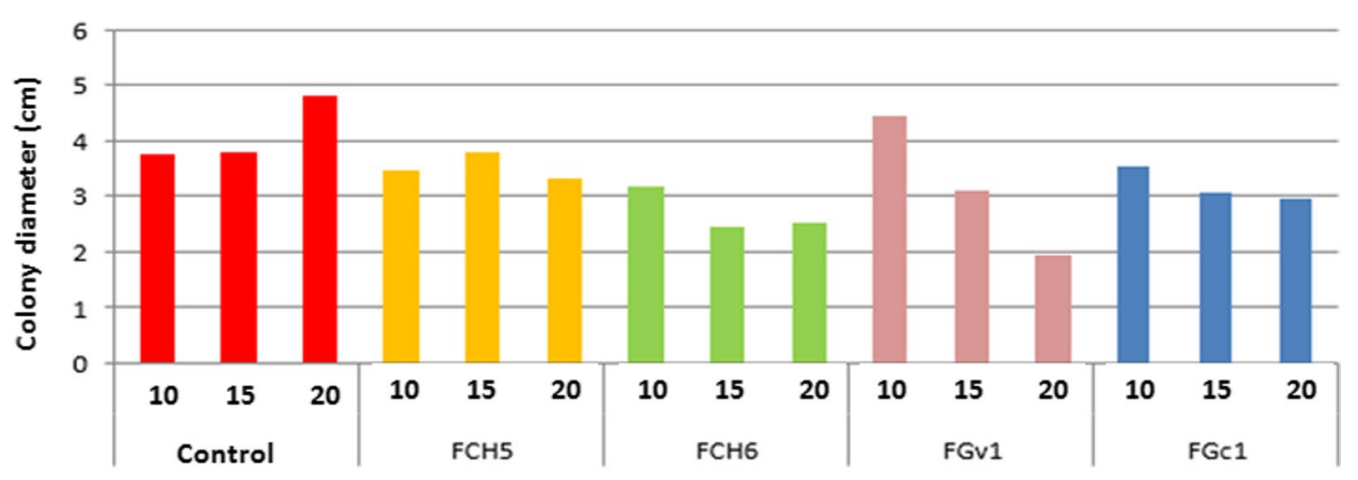

Culture filtrates tested / Concentrations used (\%v/v)

Fig. 4 Effect of three concentrations of cell-free cultural filtrates of the tested microbial agents against Colletotrichum coccodes mycelial growth noted after 9 days of incubation at $25^{\circ} \mathrm{C}$. FCH5 and FCH6: Culture filtrates of Penicillium sp. CH5 and CH6 isolates; FGv1: Cultural filtrate of Gliocladium virens Gv1; FGc1: Culture filtrate of G. catenulatum Gc1. LSD (Cultural filtrates tested $\times$ Concentrations used) $=0.45 \mathrm{~cm}$ at $P \leq 0.05$

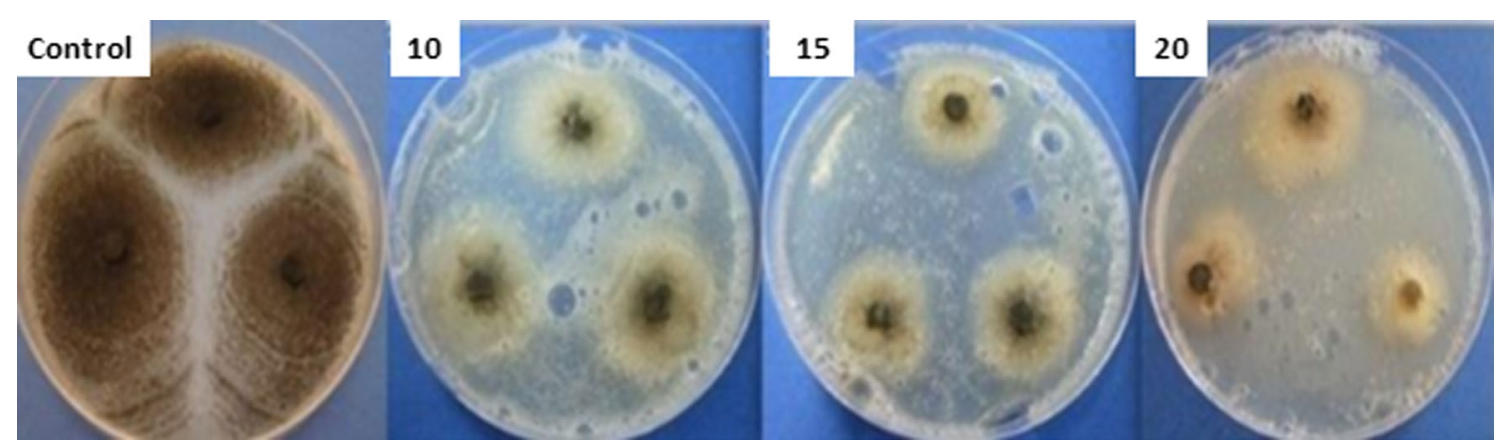

Fig. 5 Radial growth inhibition and alteration of morphological traits of Colletotrichum coccodes colonies when grown on PDA medium amended with different concentrations (\% v/v) of Penicillium sp. CH5 cell-free filtrates as compared to the untreated controls 


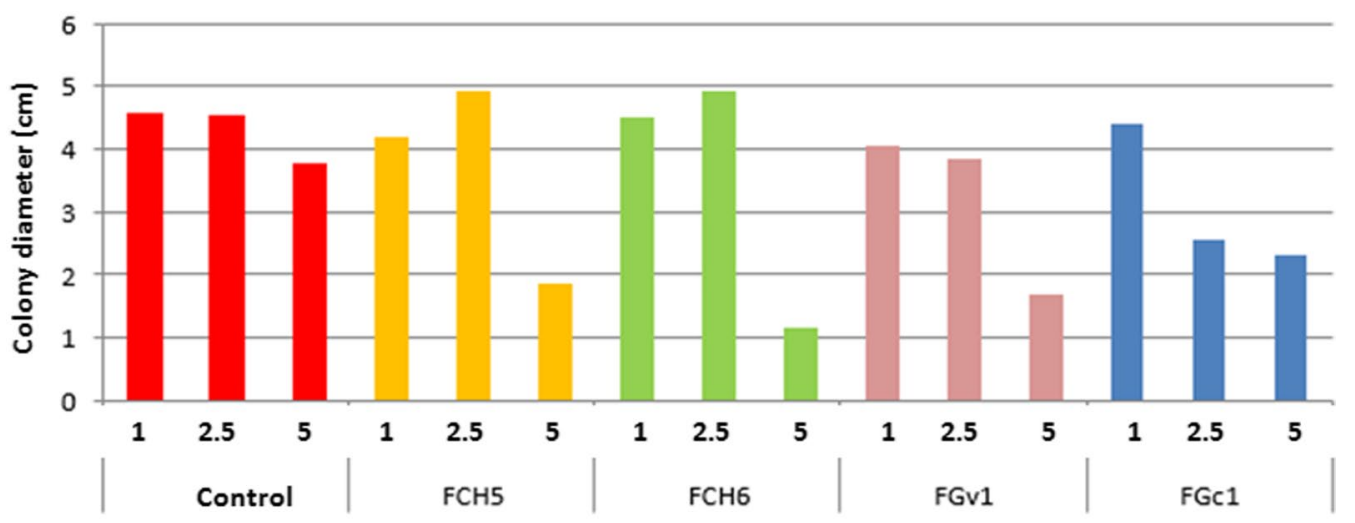

Ethyl acetate extracts tested /Concentrations used (\%v/v)

Fig. 6 Effect of three concentrations of ethyl acetate extracts from the tested microbial agents against Colletotrichum coccodes mycelial growth recorded after 9 days incubation at $25^{\circ} \mathrm{C}$. ECH5 and ECH6: Ethyl acetate extracts of Penicillium sp.CH5 and $\mathrm{CH} 6$ isolates; EGv1: Ethyl acetate extracts of Gliocladium virens Gv1; EGc1: Ethyl acetate extracts of G. catenulatum Gc1. LSD (Ethyl acetate extracts tested $\times$ Concentrations used) $=0.28 \mathrm{~cm}$ at $P \leq 0.05$

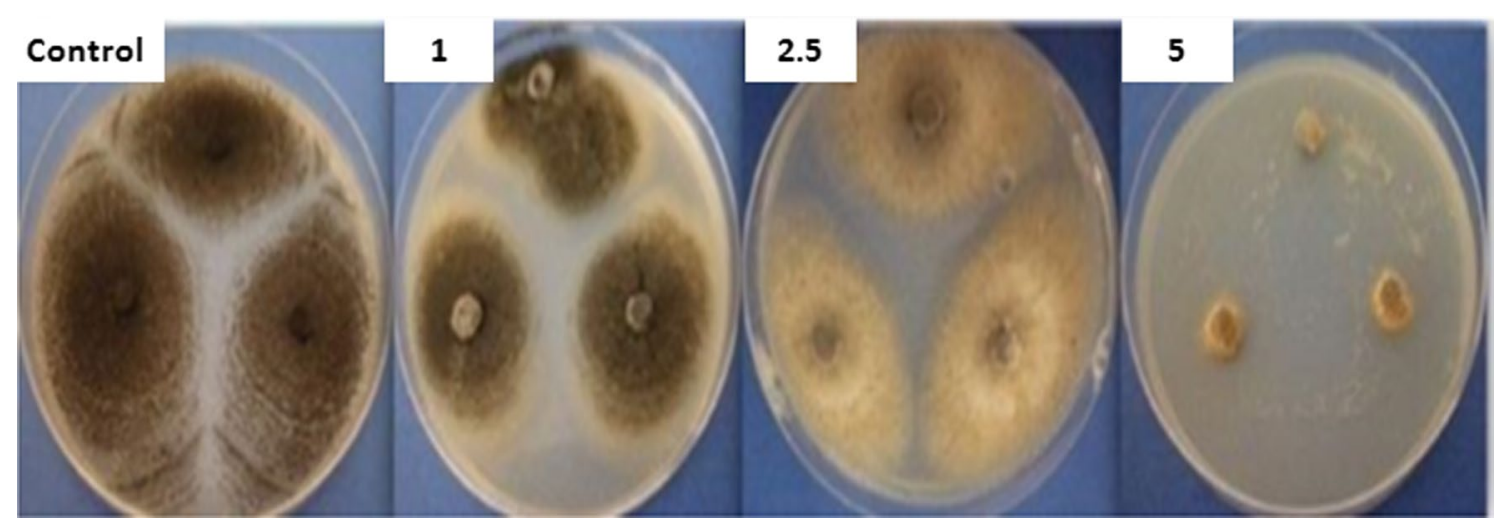

Fig. 7 Radial growth inhibition and alteration of morphological traits of Colletotrichum coccodes colonies when grown on PDA medium amended with different concentrations (\% v/v) of Penicillium sp. CH6 ethyl acetate extract as compared to the untreated controls

\section{Antifungal potential of chloroform extracts of microbial agents tested}

ANOVA analysis revealed that the diameter of pathogen colonies significantly varied (at $P \leq 0.05$ ) depending on chloroform extracts tested, concentrations added and their interactions. In fact, $C$. coccodes colonies grown on PDA medium amended with Penicillium sp. ( $\mathrm{CH} 5$ and CH6 isolates) and G. virens Gv1 chloroform extracts, and treated at $1 \% \mathrm{v} / \mathrm{v}$, showed 8 to $24 \%$ decrease in their radial growth as compared to controls. At $2.5 \% \mathrm{v} / \mathrm{v}$, pathogen growth was inhibited by 24 and $19 \%$ using Penicillium sp. $\mathrm{CH} 5$ and G. catenulatum Gc1 chloroform extracts. However, pathogen inhibition rate was raised to $84,58,44$ and 43\% when Gv1 (G. virens), Gc1 (G. catenulatum), CH6 and $\mathrm{CH} 5$ of Penicillium sp. chloroform extracts were applied at $5 \% \mathrm{v} / \mathrm{v}$, respectively. This last concentration was highly effective in inhibiting the spore germination by $100 \%$ and in alterating the morphological traits of $C$. coccodes colonies as compared to control (Figs. 9, 10, 11).

\section{Suppression of anthracnose-induced fruit decay using microbial cell-free filtrates}

The cell-free cultural filtrates of the microbial agents tested were treated on tomato fruits in order to check their ability to suppress anthracnose decay severity. ANOVA analysis revealed that the external diameter of the rot developed within treated and inoculated wounds significantly varied (at $P \leq 0.05$ ) depending on treatments tested. Data given in Fig. 12 showed that disease severity was significantly lowered by 22 to $25 \%$ versus control 


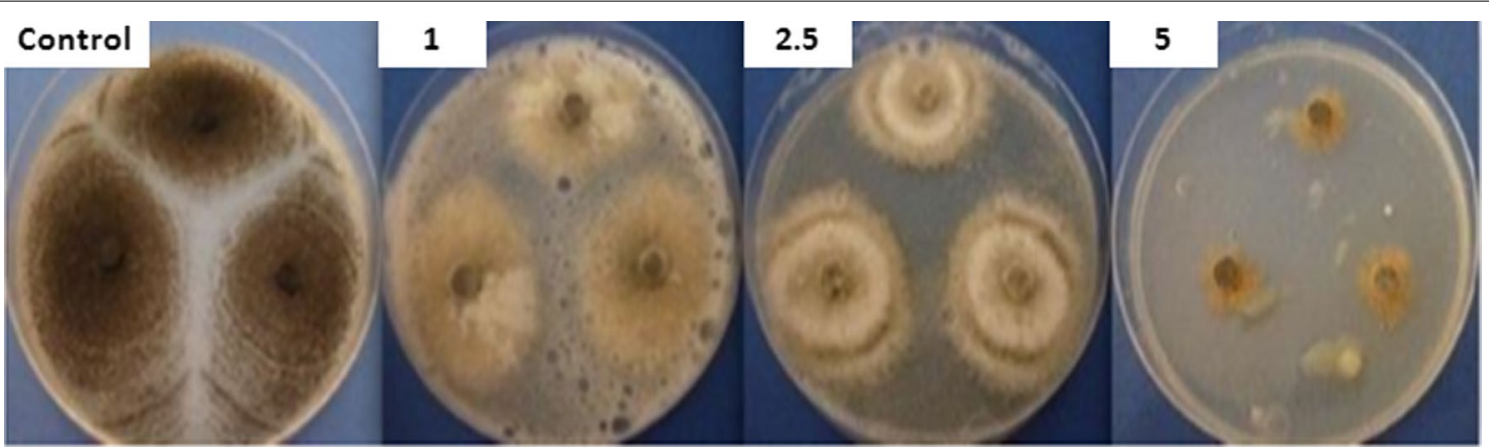

Fig. 8 Radial growth inhibition and alteration of morphological traits of Colletotrichum coccodes colonies when grown on PDA medium amended with different concentrations ( $\%$ v/v) of Gliocladium virens Gv1ethyl acetate extract as compared to the untreated controls

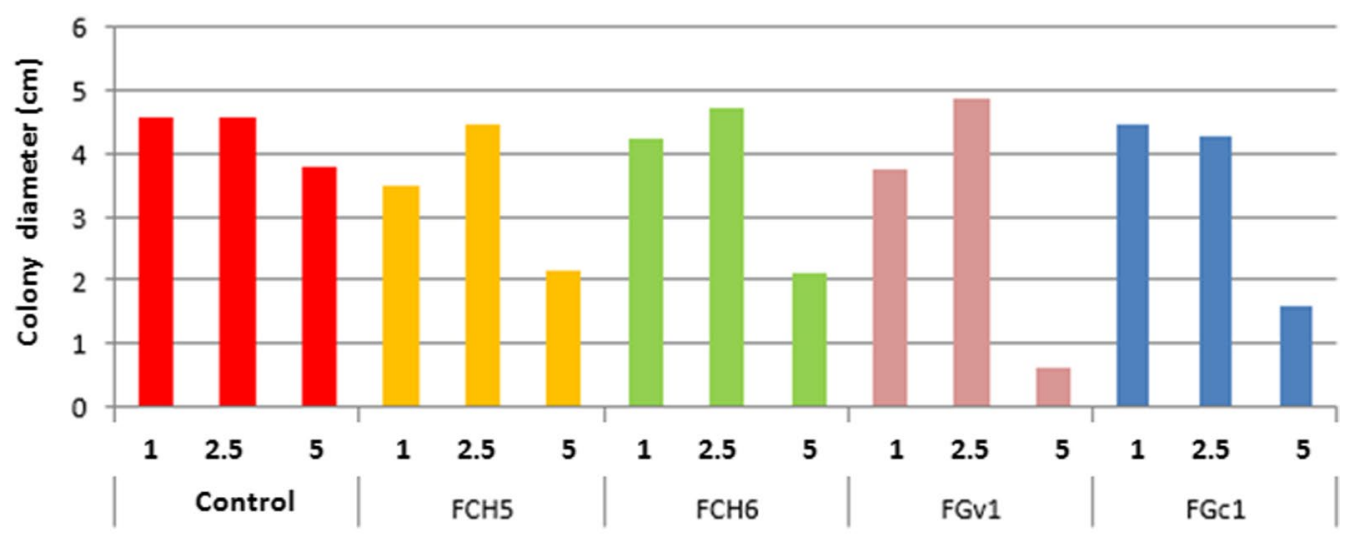

\section{Chloroform extracts tested/Concentrations used (\%v/v)}

Fig.9 Effect of three concentrations of chloroform extracts of microbial agents tested against Colletotrichum coccodes mycelial growth recorded after 9 days incubation at $25^{\circ} \mathrm{C}$. ECH5 and ECH6: Chloroform extracts of Penicillium sp. $\mathrm{CH} 5$ and $\mathrm{CH} 6$ isolates; EGv1: Chloroform extract of Gliocladium virensGv1; EGc1: Chloroform extract of G. catenulatum Gc1. LSD (Chloroform extracts tested $\times$ Concentrations used) $=0.29 \mathrm{~cm}$ at $P \leq 0.05$

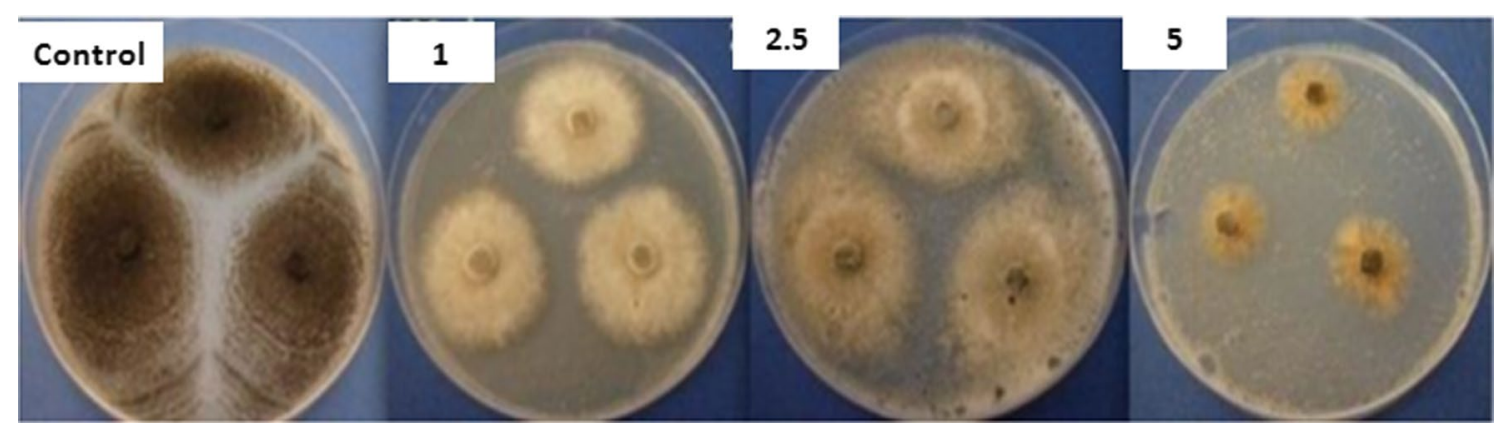

Fig. 10 Radial growth inhibition and alteration of morphological traits of Colletotrichum coccodes colonies when grown on PDA medium amended with different concentrations (\% v/v) of Penicillium sp. CH5 chloroform extract as compared to the controls

following fruit treatments with cell-free filtrates from Penicillium sp. (MC1, CH6) and G. catenulatum (Gc1) cultures but the decreases induced by the other tested treatments were not significant as compared to control (Fig. 13). 


\section{Control}

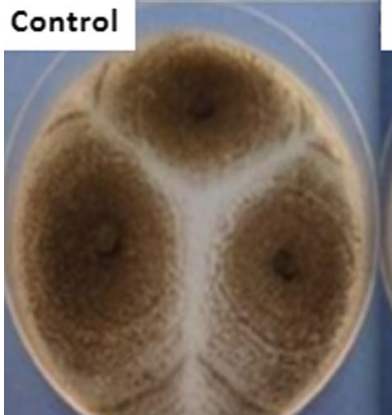

1

\section{1}

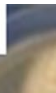

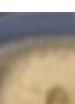
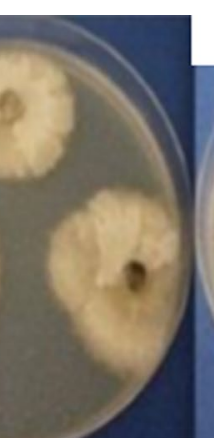

2.5
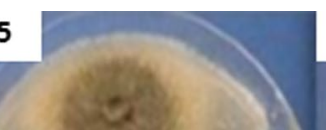

5
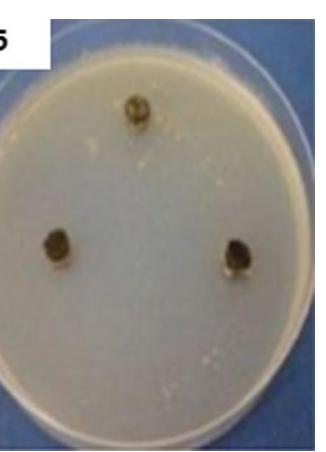

Fig. 11 Radial growth inhibition and alteration of morphological traits of Colletotrichum coccodes colonies when grown on PDA medium amended with different concentrations (\% v/v) Gliocladium virens Gv1 chloroform extract as compared to the controls

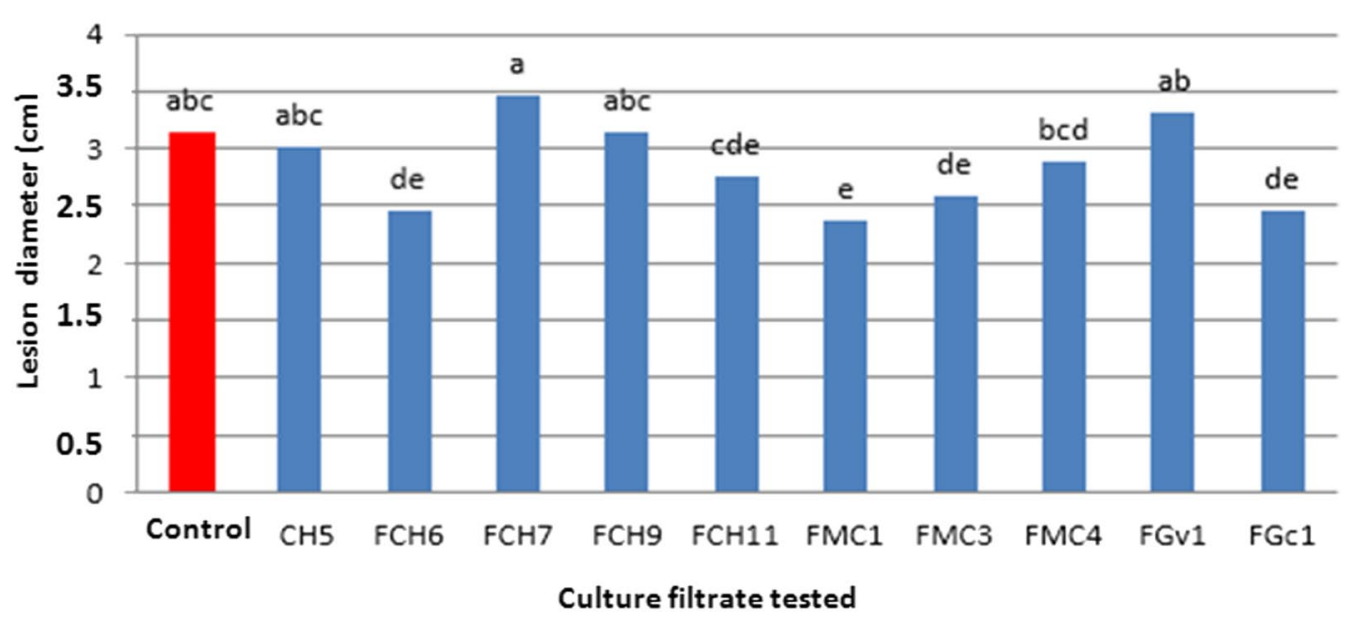

Fig. 12 Effect of various microbial cell-free cultural filtrates on anthracnose-induced decay severity on tomato fruits recorded after 7 days of incubation at $25^{\circ} \mathrm{C}$ compared to the inoculated and untreated control. FCH5, FCH6, FCH7, FCH9, FCH1 1, FMC1, FMC3 et FMC4: Culture filtrates of Penicillium sp. (isolates $\mathrm{CH} 5, \mathrm{CH} 6, \mathrm{CH} 7, \mathrm{CH} 9, \mathrm{CH} 11, \mathrm{MC1}, \mathrm{MC} 3$ andMC4); FGv1: Culture filtrate of Gliocladium virens Gv1; FGc1: Cultural filtrate of G. catenulatum Gc1. Bars sharing the same letter are not significantly different according to the test Student-Newman-Keuls at $P \leq 0.05$

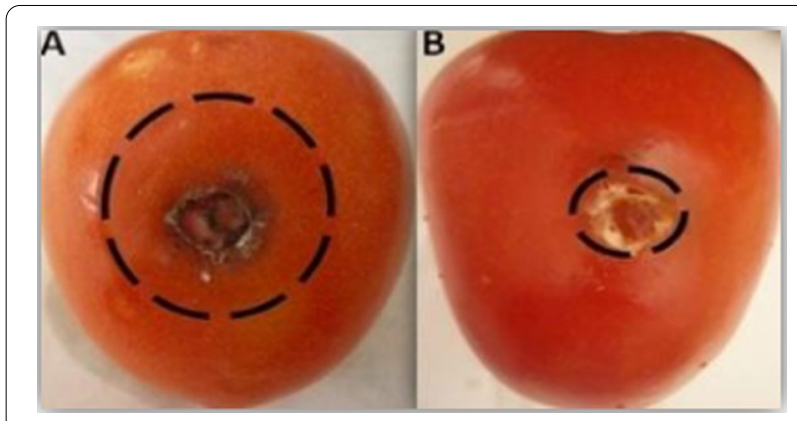

Fig. 13 Suppression of anthracnose-induced decay using the cultural filtrate of Penicillium sp. MC1 on tomato fruits (B) as compared to pathogen-inoculated and untreated control (A) recorded after 7 days of incubation at $25^{\circ} \mathrm{C}$. The black dots are added to delimit the dimensions of the anthracnose-induced decay on tomato fruits

\section{Suppression of anthracnose-induced fruit decay using microbial organic extracts}

Organic extracts of the four most effective microbial cellfree filtrates were further screened for their capacity to suppress $C$. coccodes development on tomato fruits. The diameter of rot lesion, which induced after 7 days of incubation at $25{ }^{\circ} \mathrm{C}$, varied significantly (at $P \leq 0.05$ ) depending on extracts tested. In fact, anthracnose-induced decay severity was significantly reduced by 14 to $85 \%$ using ethyl acetate extracts from Penicillium sp. $\mathrm{CH} 5$ and $\mathrm{CH} 6$ isolates, G. catenulatum Gc1, and G. virens Gv1 (Fig. 14a, $15)$. However, the inhibition rates which were recorded following treatments with chloroform extracts ranged between 11 and 59\% (Figs. 14b, 16). 

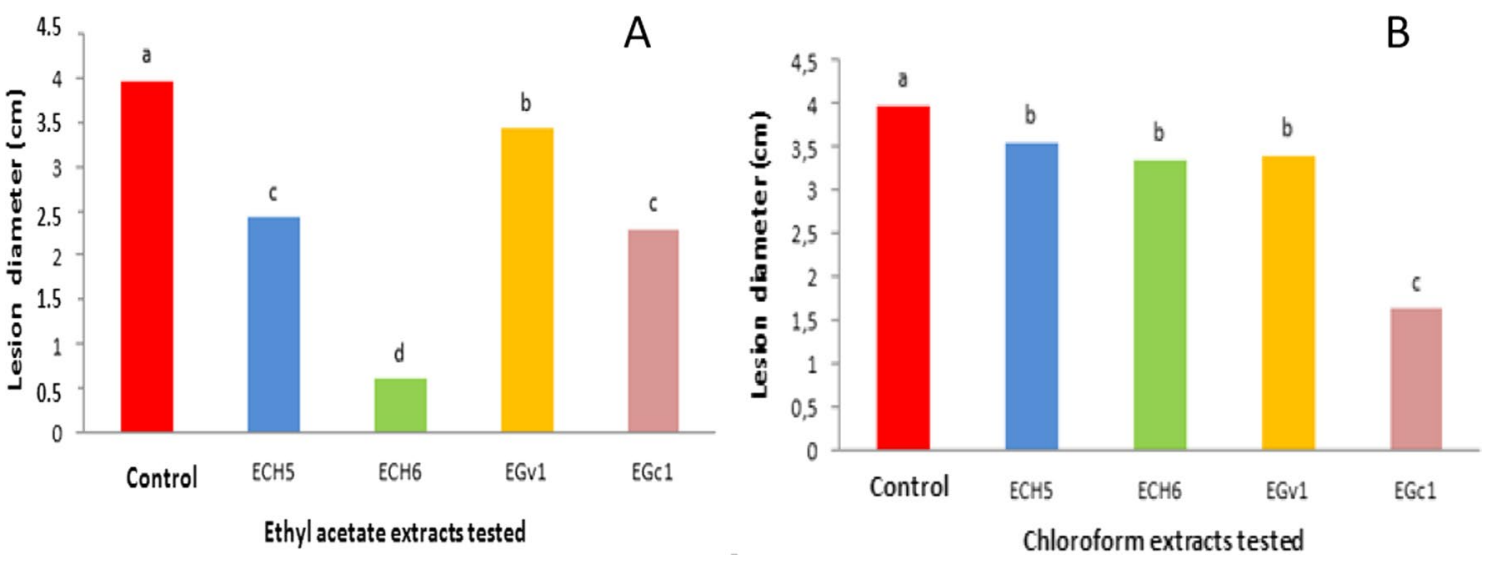

Fig.14 Effect of the ethyl acetate (a) and chloroform (b) extracts of the microbial agents tested on the severity of anthracnose-induced decay on tomato fruits noted 7 days of incubation at $25^{\circ} \mathrm{C}$ as compared to pathogen-inoculated and untreated control. ECH5 and ECH6: Ethyl acetate and chloroform extracts of Penicillium sp. isolates $\mathrm{CH} 5$ and CH6; EGv1: Ethyl acetate and chloroform extract of Gliocladium virens Gv1; EGc1: Ethyl acetate and chloroform extract of $\mathrm{G}$. catenulatum Gc1. Bars sharing the same letter are not significantly different according to the Student-Newman-Keuls test at $P \leq 0.05$

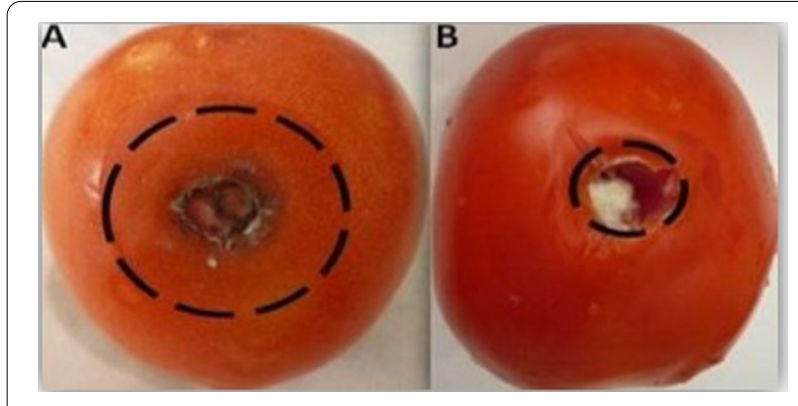

Fig. 15 Suppression of anthracnose-induced decay using the ethyl acetate extract of Gliocladium catenulatum Gc1 on tomato fruits (b) as compared to pathogen-inoculated and untreated control (a) recorded after 7 days of incubation at $25^{\circ} \mathrm{C}$. The black dots are added to delimit the dimensions of anthracnose-induced decay on tomato fruits

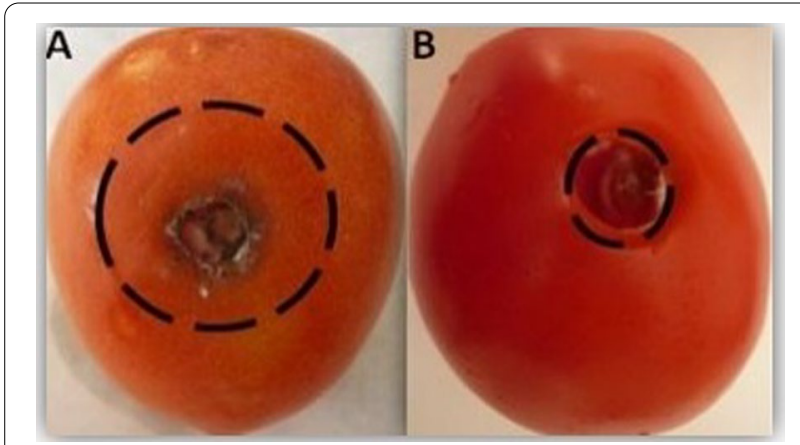

Fig. 16 Suppression of anthracnose-induced decay using the chloroform extract of GliocladiumcatenulatumGc1 on tomato fruits (b) as compared to pathogen-inoculated and untreated control (a) recorded after 7 days of incubation at $25^{\circ} \mathrm{C}$. The black dots are added to delimit the dimensions of anthracnose on tomato fruits

\section{Discussion}

Inhibitory effect of biocontrol agents tested was observed using the cultural filtrate and the different organic extracts. Similar trend was recorded with the cultural filtrate from $T$. harzianum against $C$. coccodes growth (Maurya et al. 2008). Bridžiuvienè and Repečkienè (2009) also demonstrated the antifungal potential of $T$. virens and Penicillium sp. cultural filtrates toward various Colletotrichum species. The cell-wall-degrading enzymes (CWDEs), such as chitinase and $\beta$-1,3-glucanase, released in the cellfree cultural filtrates were responsible of the inhibition of C. gloeosporioides (Ruangwong et al. 2021). The cultural filtrate of T. viride and Pseudomonas fluorescens were very effective in inhibiting the mycelial growth of C. capsici, the causal agent of anthracnose on chili (Sonawane and Shinde 2021). Okhovvat (1997) also highlighted the antifungal potential of T. viride and T. harzianum cultural filtrates against $C$. coccodes growth which ranged between 18 and $55 \%$ when used at 3.5 to $5 \% \mathrm{v} / \mathrm{v}$, respectively. Also, some bacterial cell-free culture filtrates such as those of Bacillus amylolique faciens displayed antifungal activity against several phytopathogenic fungi including C. dematium where this effect was more attributed to antibiotics released in these filtrates (Yoshida et al. 2002). Similarly, the application of the cultural filtrate of the novel endophytic bacterium, Stenotrophomonas maltophilia at $1 \mathrm{ml}$ has suppressed $C$. nymphaeae mycelial growth (Alijani et al. 2020). Likewise, the sterile cultural filtrate of $B$. subtilis has shown an important inhibitory effect toward various fungal phytopathogens including $C$. gloeosporioides (Huang et al. 2020). Moreover, these findings of the present study are in agreement with Shu et al. (2017) results where similar inhibitory effects of Streptomyces katrae 
cell-free culture filtrates were recorded against C. musae conidial germination. The treatment of the cultural filtrate of the entomopathogenic fungus (genus Cordyceps) has also reduced under in vitro conditions the conidial germination of all Colletotrichum spp. isolates tested (Jaihan et al. 2016). The hyphal destruction and the inhibition of conidial germination were induced by the cultural filtrate of Streptomyces deccanensis on C. gloeosporioides (Gu et al. 2020). A positive correlation between the levels of the culture filtrate efficacy and the increase in their concentrations was recorded. Therefore, a similar variations in the inhibitory effects depending on concentrations were reported in the case of $B$. licheniformis filtrates against $C$. gloeosporioides and treated at different dilutions $(10,100,200,400,800$ and 1000 times) when the highest antifungal potential was noted at the dilution 200 (He et al. 2009). Moreover, Serratia marcescens cultural filtrates used at 40 and $50 \% \mathrm{v} / \mathrm{v}$ had completely limited C. lindemuthianum mycelial growth, mycelial dry weight and conidial germination (Papitha et al. 2020). Similarly, T. viride, T. harzianum, T. reesei and T. saturnisporum filtrates, which were used at $0,5,10,25$ and $50 \% \mathrm{v} / \mathrm{v}$, had suppressed C. capsici growth by 21 to $68 \%$ over control when the highest antifungal potential was recorded at the concentration $50 \% \mathrm{v} / \mathrm{v}$ (Ajith and Lakshmidevi 2010). An interesting efficiency was also noted using the cultural filtrates of 19 isolates of T. asperellum and one isolate of T. harzianum at 10 and $25 \% \mathrm{v} / \mathrm{v}$ against C. graminicola mycelial growth. This highest growth inhibiting effect, which estimated at 68.18 and $80.68 \%$ over control, was noted using T. asperellum at 10 and $25 \% \mathrm{v} / \mathrm{v}$, respectively (Manzar and Singh 2020). However, Padder and Sharma (2011) study as a significant decrease in C. lindemuthianum spore germination was noted using T. harzianum, T. viride, G. virens and T. hamatum cultural filtrates at 25 and $50 \% \mathrm{v} / \mathrm{v}$. The serial dilutions of T. viride at $5,10,15$ and $20 \% \mathrm{v} / \mathrm{v}$ had also inhibited C. gloeosporiodes mycelial growth and spore germination with the highest inhibitory effect, by $90.90 \%$ over control, was noted at $20 \% \mathrm{v} / \mathrm{v}$ (Yasmin and Shamsi 2019). Similar inhibitory effect was obtained with the different organic extracts of the biocontrol agents tested on the present study with the serial dilutions. Similar findings were noted by Pornsuriya et al. (2010) using ethyl acetate, n-hexanoic and methanolic extracts of G. catenulatum and T. harzianum isolates for the control of Pythium aphanidermatum, the causal agent of pine apple root rot. These authors also reported the effect of ethyl acetate extracts from isolates of G. virens and Penicillium spp. on P. aphanidermatum at 0, 10, 50, 100,500 and $1000 \mu \mathrm{g} / \mathrm{ml}$.

However, several previous studies reported the effectiveness of microbial culture filtrates against postharvest pathogens as was the case of Palaniyandi et al. (2011) study who found that Streptomyces filtrates had reduced anthracnose incidence and severity under controlled conditions by $85-88 \%$ over control. Nevertheless, some filtrates have reduced anthracnose severity and pathogen sporulation at the inoculation site as Bosah et al. (2010) whom showed the ability of Penicillium sp. isolates to reduce Sclerotium sp. mycelial development through the production of antibiotics. This reduction of fruit infection levels was also recorded using cell-free filtrates from T. viridae, T. pseudokoningii and T. harzianum cultures against C. capsici development (Rahman et al. 2018). In addition, the application of T. harzianum culture filtrate under greenhouse conditions has reduced greatly disease severity associated to C. sublineolum infection and has also concomitantly promoted sorghum growth (Saber et al. 2017). Recently, Ruangwong et al. (2021) demonstrated the effectiveness of T. koningiopsis culture filtrate in controlling C. gloeosporioides on chili pepper and recorded no disease symptoms following treatments. Similar decreases in disease lesion and severity on chili pepper (C. gloeosporioides) were also observed by Jaihan et al. (2016) using the culture filtrate of the entomopathogenic fungus Ophiocordyceps sobolifera. Similar disease suppressive effects have been obtained by Ara et al. (2012) using $50 \mu \mathrm{l}$ of methanolic extracts of the actinomycete bacterium (Streptomyces sp.) for the control of $C$. musae on banana fruits. The n-butanol extracted of the chitinolytic bacterium Paenibacillus ehimensis has also completely inhibited the spore germination of the phytopathogen C. gleosporioides on pepper fruits (Anees et al. 2019). Similarly, the ethanol extracts of O. sobolifera applied at $50 \%(\mathrm{v} / \mathrm{v})$ on chili pepper have also reduced anthracnose severity and symptom appearance associated to C. capsici and C. gloeosporioides infections under pot conditions (Jaihan et al. 2018). The ethyl acetate extract of the endophytic fungus Epicoccum dendrobii has eventually suppressed C. gleosporioides development on detached leaves of Chinese fir (Bian et al. 2021).

\section{Conclusions}

The present study demonstrated the antifungal activity of cell-free cultural filtrates and organic extracts of microbial agents (Penicillium sp. and Gliocladium spp.) tested against the in vitro and the in vivo growth of $C$. coccodes. The most effective bio-agents in controlling $C$. coccodes pathogen mycelial growth and anthracnose severity on tomato fruits were $\mathrm{CH} 6$ of Penicillium sp. and Gc1 of G. catenulatum. Further experiments are needed for the identification of the nature of chemical compounds involved in the recorded antifungal activity by the highperformance liquid chromatography (HPLCMAS) for the corresponding solvent extract. 


\section{Abbreviations}

C. coccodes: Colletotrichum coccodes; C. capsici: Colletotrichum capsici; C.: dematium: Colletotrichum dematium; C. nymphaeae: Colletotrichum nymphaeae; C. graminicola: Colletotrichum graminicola; C. lindemuthianum: Colletotrichum lindemuthianum; C. acutatum: Colletotrichum acutatum; C. sublineolum: Colletotrichum sublineolum; C. musae: Colletotrichum musae; C. lindemuthianum: Colletotrichum lindemuthianum; C. gloeosporioides: Colletotrichum gloeosporioides; G. catenulatum: Gliocladiumcatenulatum; G. virens: Gliocladiumvirens; PDA: Potato dextrose agar; PDB: Potato dextrose broth; T. harzianum: Trichoderma harzianum; T. virens: Trichoderma virens; T. viride: Trichoderma viride; T. reesei: Trichoderma reesei; T. saturnisporum: Trichoderma saturnisporum; T. hamatum: Trichoderma hamatum; T. atroviride: Trichoderma atroviride; T. asperellum: Trichoderma asperellum; T. pseudokon: ingii: Trichoderma pseudokoningii; T. koningiopsis: Trichoderma koningiopsis; B. subtilis: Bacillus subtilis; B. licheniformis: Bacillus licheniformis; O. sobolifera: Ophiocordyceps sobolifera..

\section{Acknowledgements}

Authors would like to thank the Ministry of Higher Education and Scientific Research of Tunisia and the exceptional support of the laboratory technicians.

\section{Authors' contributions}

The concept and design of the experiments were prepared by all authors. $\mathrm{MH}$ carried out the experiment, collected the data, performed the analysis and wrote the paper. RAB and HJK coordinated the laboratory works and helped in the writing paper. MDR supervised the results analysis and corrected the manuscript draft. All authors have read and approved the manuscript.

\section{Funding}

This work was funded by the Ministry of Higher Education and Scientific Research of Tunisia through the funding allocated to the Research Laboratory LR21AGR03-Production and Protection for a Sustainable Horticulture (2PHD), Regional Research Centre on Horticulture and Organic Agriculture of Chott Mariem, Tunisia.

\section{Availability of data and materials}

All data generated and/or analyzed during the present study are available in the manuscript, and the corresponding author has no objection to the availability of data and materials.

\section{Declarations}

\section{Ethics Approval and Consent to participate}

The study was conducted on plant-pathogen fungus and beneficial Fungus that are abundant in the environment and does not require ethical approval.

\section{Consent for publication}

Not Applicable.

\section{Competing interests}

All authors declare that they have no conflict of interest.

\section{Author details}

'LR14AGR01, Laboratory of Genetics and Cereal Breeding, National Agronomic Institute of Tunisia, University of Carthage, Avenue Charles Nicolle 43, 1082 Tunis, Tunisia. ${ }^{2}$ LR21AGR03-Production Et Protection Pour Une Horticulture Durable (2PHD), Centre Regional Des Recherches en Horticulture Et Agriculture Biologique (CRRHAB), Universite de Sousse, 4042 Chott-Mariem, Tunisie.

Received: 1 December 2021 Accepted: 22 February 2022 Published online: 01 March 2022

\section{References}

Ajith PS, Lakshmidevi N (2010) Effect of volatile and nonvolatile compounds from Trichoderma spp. against Colletotrichum capsici incitant of Anthracnose on Bell. Nat Sci 8(9):265-269

Alijani Z, Amini J, Ashengroph M, Bahramnejad B (2020) Volatile compounds mediated effects of Stenotrophomonas maltophilia strain UN1512 in plant growth promotion and its potential for the biocontrol of Colletotrichum nymphaeae. Physiol Mol Plant Pathol 112:101555. https://doi.org/10. 1016/j.pmpp.2020.101555

Alkan N, Davydov O, Sagi M, Fluhr R, Prusky D (2009) Ammonium secretion by Colletotrichum coccodes activates host NADPH oxidase activity enhancing host cell death and fungal virulence in tomato fruits. Mol Plant-Microbe Interact 22(12):1484-1491. https://doi.org/10.1094/ MPMI-22-12-1484

Anees M, Abid M, ur Rehman S, Ahmed N, Ashraf M, Zhang L, Kim KY (2019) Antifungal activity of various chitinolytic bacteria against Colletotrichum in pepper. Plant Pro Sci 55(2): 109-115. https://doi.org/10.17221/72/ 2018-PPS

Ara I, Rizwana H, Al-Othman MR, Bakir MA (2012) Studies of actinomycetes for biological control of Colletotrichum musae pathogen during post harvest anthracnose of banana. Afr J Microbiol Res 6(17):3879-3886. https://doi. org/10.5897/AJMR12.088

Atalla SM, Ahmed NE, Awad HM, EIGamal NG, EIShamy AR (2020) Statistical optimization of xylanase production, using different agricultural wastes by Aspergillus oryzae MN894021, as a biological control of faba bean root diseases. Egypt J Biol Pest Control 30(1):1-12

Badawy MEl, Rabea El (2009) Potential of the biopolymer chitosan with different molecular weights to control postharvest grey mold of tomato fruit. Postharvest Biol Technol 51:110-117. https://doi.org/10.1016/j.posth arvbio.2008.05.018

Bian JY, Fang YL, Song Q, Sun ML, Yang JY, Ju YW, Li DW, Huang L (2021) The fungal endophyte Epicoccum dendrobii as a potential biocontrol agent against Colletotrichum gloeosporioides. Phytopathology 111(2):293-303. https://doi.org/10.1094/PHYTO-05-20-0170-R

Bosah O, Igeleke CA, Omorusi VI (2010) In vitro microbial control of pathogenic Sclerotium rolfsii. Int J Agric Biol 12(3):474-476

Bridžiuvienè D, Repečkienè J (2009) Interspecific relation peculiarities between soil and phytophatogenic fungi. Sci Works Lithuanian Inst Hortic Lithuanian, Univ Agric 28:19-28

Comporta P (1985) In vitro Antagonism of Trichoderma spp. vis-à-vis Rhizoctonia solani Kühn. Agron 5:613-620

Cwalina-Ambroziak B, Nowak M (2012) The effects of biological and chemical controls on fungal communities colonising tomato (Lycopersicon esculentum Mill.) plants and soil. Folia Hortic 24(1):13-20. https://doi.org/10. 2478/v10245-012-0002-4

Daami-Remadi M, Dkhili I, Jabnoun-Khiareddine H, El Mahjoub M (2012) Biological control of potato leak with antagonistic fungi isolated from compost teas and solarized and non-solarized soils. Pest Technol 6:32-40

Dennis C, Webster J (1971) Antagonisme properties of species of Trichoderma: Production of volatile antibiotics. Trans Brit Mycol Soci 57:41-48

Fu J, Zhou Y, Li HF, Ye YH, Guo JH (2011) Antifungal metabolites from Phomopsis sp. By254, an endophytic fungus in Gossypium hirsutum. Afr J Microbiol Res 5:1231-1236

Gilardi G, Pugliese M, Colla P, Gullino ML, Garibaldi A(2014) Management of Phytophthoracapsici on bell pepper and Colletotrichumcoccodes on tomato by using grafting and organic amendments. In: VIII international symposium on chemical and non-chemical soil and substrate disinfestation vol 1044, pp 257-262

Gu L, Zhang K, Zhang N, Li X, Liu Z (2020) Control of the rubber anthracnose fungus Colletotrichum gloeosporioides using culture filtrate extract from Streptomyces deccanensis QY-3. Antonie van Leeuwenhoek 113(11):15731585. https://doi.org/10.1007/s10482-020-01465-8

He L, Zhou G, Lu L, Liu J (2009) Isolation and identification of endophytic bacteria antagonistic to Camellia oleifera anthracnose. Afr J Microbiol Res 3(6):315-318

Huang H, Tian C, Huang Y, Huang H (2020) Biological control of poplar anthracnose caused by Colletotrichum gloeosporioides (Penz.) Penz. \& Sacc. Egypt J Biol Pest Control 30(1): 1-9. https://doi.org/10.21315/tlsr2019.30.1.7

Ibrahim AD, Hussaini H, Sani A, Aliero AA, Yakubu SE (2011) Volatile metabolites profiling to discriminate diseases of tomato fruits inoculated with three toxigenic fungal pathogens. Res Biotechnol 2:14-22

Jaihan P, Sangdee K, Sangdee A (2016) Selection of entomopathogenic fungus for biological control of chili anthracnose disease caused by Colletotrichum spp. Eur J Plant Pathol 146(3):551-564

Jaihan P, Sangdee K, Sangdee A (2018) Disease suppressive activity of extracts from entomopathogenic fungus Ophiocordyceps sobolifera against chili 
anthracnose fungi Colletotrichum spp in a pot experiment. J Gen Plant Pathol 84(3):237-242

Jinal NH, Amaresan N (2020) Evaluation of biocontrol Bacillus species on plant growth promotion and systemic-induced resistant potential against bacterial and fungal wilt-causing pathogens. Arch Microbiol. https://doi. org/10.1007/s00203-020-01891-2

Kubicek CP, Harman GE (1998) Trichoderma and Gliocladium. Basic biology, taxonomy and genetics (Vol 1), Academic Press, London, 278

Lepengue NA, Mouaragadja I, M'Batchi B, Ake S (2009) Study of some physicochemical characteristics of the toxic filtrate of Phoma sabdariffae Sacc Pathogen of the Roselle. Sci Nat 6:95-105

Maatougui MEH, Merzoug A (1997) Study on Botrytis fabae Sard: optimal conditions of in vitro culture on three isolates collected in western Algeria and test of the reaction of bean and faba bean genotypes: Mediterranean food legumes. INRA, Paris

Manzar N, Singh Y (2020) Evaluation of the efficacy of culture filtrate of Trichoderm a Isolates against Colletotrichum graminicola causing anthracnose of sorghum. Int J Curr Microbiol App Sci 9(1):820-825

Maurya S, Singh R, Singh D, Singh H, Singh U, Srivastava J (2008) Management of collar rot of chickpea (Cicer arietinum) by Trichoderma harzianum and plant growth promoting rhizobacteria. J Plant Prot Res 48(3):347-355

Miftahurrohmat A, Nurmalasari IR, Prihatinnigrum AE (2021) In vitro evaluation of the inhibitory power of Trichoderma harzianumagainst pathogens that cause Anthracnose in Chili. In: Journal of physics: conference series, vol 1764, p 012026. IOP Publishing

Mónaco C, Bello D, Rollán MC, Ronco L, Lampugnani G, Abramoff C, Aprea A, Larran S, StoccM, (2009) Biological control of Botrytis cinerea on tomato using naturally occurring fungalantagonists. Arch Phytopathol Plant Prot 42:729-737

Okhovvat M (1997) In vitro antagonistic effects of Trichoderma spp on several soil-borne plant pathogenic fungi. J Sci Islam Repub Iran 8(2):86-95

Opeyemi BS, Temidayo BR, Babalola YO, Emmanuel IB, Ojubolamo MT, Folake AB (2018) Biological control of anthracnose disease of tomato using ethanolic extracts of Azadirachta Indica and Nicotiana Tabacum. Int Ann Sci 4(1):20-26

Padder BA,\&Sharma PN, (2011) In vitro and in vivo antagonism of biocontro agents against Colletotrichum lindemuthianum causing bean anthracnose. Arch Phytopathol Plant Protect 44:961-969

Palaniyandi SA, Yang SH, Cheng JH, Meng L, Suh JW (2011) Biological control of anthracnose (Colletotrichum gloeosporioides) in yam by Streptomyces sp. MJM5763. J Appl Microbiol 111(2):443-455. https://doi.org/10.1111/j. 1365-2672.2011.05048.x

Papitha K, Sanjeevkumar K, Balabaskar P, Kumar S (2020) Bioefficacy evaluation of Serratia marcescens against anthracnose (Colletotrichum Lindemuthianum) disease in dolichos bean. Plant Arch 20(1):493-496

Pornsuriya C, Soytong K, Kanokmedhakul S, Lin FC (2010) Efficacy of antifungal metabolites from some antagonistic fungi against Pythium aphanidermatum. J Agric Technol 6(2):299

Rahman MA, Ansari TH, Alam MF, Moni JR, Ahmed M (2018) Efficacy of Trichoderma against Colletotrichum capsicicausing fruit rot due to Anthracnose of Chili (Capsicum annum L.). The Agriculturists 16(02):75-87

Riahi A, Hdider C, Sanaa M, Tarchoun N, Ben Kheder M, Guezal I (2009) Effect of conventional and organic production systems on the yield and quality of field tomato cultivars grown in Tunisia. J Sci Food Agric 89(13):2275-2282

Ridzuan R, Rafii MY, Ismail SI, Mohammad Yusoff M, Miah G, Usman M (2018) Breeding for anthracnose disease resistance in chili: progress and prospects. Int J Mol Sci 19(10):3122-3143

Ruangwong OU, Pornsuriya C, Pitija K, Sunpapao A (2021) Biocontrol mechanisms of Trichoderma koningiopsis PSU3-2 against postharvest anthracnose of chili pepper. J Fung 7(4):276

Saber WI, Ghoneem KM, Rashad YM, Al-Askar AA (2017) Trichoderma harzianum WKY1: an indole acetic acid producer for growth improvement and anthracnose disease control in sorghum. Biocontrol Sci Technol 27(5):654-676

Sanoubar R, Barbanti L (2017) Fungal diseases on tomato plant under greenhouse condition. Eur J Biol Res 7(4):299-308

Shu C, Chen Q, Pi L, Zhang D, Panhwar QA, Zhou E (2017) Identification and antifungal activity analysis of two biocontrol antagonists to Colletotrichum musae. J Phytopathol 165(7-8):554-561
Smoui S (2010) Purification and characterization of biomolecules from newly isolated and identified microorganisms. National Polytechnic Institute of Toulouse, University of Toulouse, France

Sonawane VB, Shinde HP (2021) Anthracnose disease of Capsicum annuum L. and its biocontrol management: A Review. Appl Ecol Environ Sci 9(2):172-176

Yasmin Z, \& Shamsi S (2019) Antagonistic potential of soil fungi against Colletotrichum gloeosporiodes (Penz.) Sacc., the causal agent of anthracnose of Rauwolfia serpentina (L.) Benth. ex Kurz. Dhaka Univ J Biol Sci 28(2): 219-226

Yoshida S, Shirata A, Hiradate S (2002) Ecological characteristics and biological control of mulberry anthracnose. Jpn Agric Res Quart JARQ 36(2):89-95

You F, Han T, Wu J, Huang B, Qin L (2009) Antifungal secondary metabolites from endophytic Verticillium sp. Biochem Syst Ecol 37:162-165

Zain ME, El-Sheikh HH, Soliman HG\& Khalil AM, (2011) Effect of certain chemical compounds on secondary metabolites of Penicillium janthinellum. J Saudi Chem Soc 15:239-246

\section{Publisher's Note}

Springer Nature remains neutral with regard to jurisdictional claims in published maps and institutional affiliations.

\section{Submit your manuscript to a SpringerOpen ${ }^{\circ}$ journal and benefit from:}

- Convenient online submission

- Rigorous peer review

- Open access: articles freely available online

- High visibility within the field

- Retaining the copyright to your article

Submit your next manuscript at $\boldsymbol{\nabla}$ springeropen.com 